\title{
Patentability of Genome-Edited Plants: A Convoluted Debate
}

\author{
Hans-Georg Dederer
}

Published online: 4 June 2020

(C) The Author(s) 2020

On 14 May2020, the Enlarged Board of Appeal (EBA) of the European Patent Office (EPO) handed down a long-awaited decision ${ }^{1}$ on the interpretation of Art. 53(b) of the European Patent Convention (EPC). Applying a "dynamic" interpretative approach, the EBA held that, in light of Rule 28(2) EPC adopted in 2017, Art. 53(b) EPC has to be construed broadly. ${ }^{2}$ According to the EBA, the exception to patentability laid down in Art. 53(b) $\mathrm{EPC}^{3}$ is not limited to process claims but extends to "product claims and product-by-process claims directed to plants, plant material and animals, if the claimed product is exclusively obtained by means of an essentially biological process or if the claimed process features define an essentially biological process".

This landmark decision does, still, not rule out the patentability of genome-edited plants, even less the patentability of breeding methods involving genome editing which produce specific traits in particular plants. Obviously, genome-edited plants (i.e. the claimed products) are not "exclusively" obtained through an essentially biological process and the properties of the breeding techniques (i.e. the claimed process features) do not define an essentially biological process. For such processes "consist[...] entirely of natural phenomena such as crossing or selection" (Rule 26(5) EPC), which is not the case in the event of plant breeding through genome editing.

\footnotetext{
1 Case G 3/19.

2 Overruling its own prior decisions in cases G 2/12 and G 2/13 of 2016, which required a narrow reading of Art. 53(b) EPC.

3 "European patents shall not be granted in respect of ... (b) ... essentially biological processes for the production of plants or animals; ..." (emphasis added).
}

H.-G. Dederer ( $₫)$

Full Professor, Chair of Constitutional and Administrative Law, Public International Law, European and International Economic Law, Faculty of Law, University of Passau, Passau, Germany e-mail: Hans-Georg.Dederer@Uni-Passau.de 
Nonetheless, the EBA's decision of 14 May 2020 leads directly to the heart of the convoluted debate on the patenting of genome-edited plants. Depending on the kind of technique used, genome editing may induce mere mutations, i.e. deletions, insertions or exchanges of only one or a few base pairs. The characteristic of such slight genetic alterations is that they cannot be distinguished from mutations which occur naturally (e.g. during cell division or due to ultraviolet radiation from the sun) or which arise from traditional ("natural") breeding techniques (e.g. crossing and selection). Accordingly, the outcome of genome editing may look just the same as the result of an essentially biological process. In other words, and in view of the EBA's decision of 14 May 2020, a patentable genome-edited plant can be indistinguishable from a non-patentable plant resulting from a non-patentable essentially biological process.

It is argued ${ }^{4}$ that this runs counter the object and purpose of Art. 53(b) EPC. Indeed, the telos of that provision might be that plant breeders should have free access to essentially biological processes for the production of plants. Plant breeders might refrain from making use of such processes, however, if they fear to be subjected to patent infringement proceedings because their resultant plants might look just the same as patented genome-edited plants, i.e. exhibit identical traits (e.g. an improved ingredient) due to congruent mutations. This teleological argumentation may be cast into doubt, though. In light of the travaux préparatoires concerning the EU's Biotechnology Directive 98/44/EC, ${ }^{5}$ the very reason for the exclusion of "essentially biological processes" from patentability may have simply been that such processes "do not meet the general conditions for patentability, as they are neither inventive nor reproducible". 6

Be that as it may, traditional plant breeders might, nevertheless, fear to encounter difficulties whenever they market newly developed plant varieties which look just the same as patented genome-edited plants regarding their traits and underlying mutations. In fact, a patent holder might claim that the plant breeder developed the plant variety without a licence as required under the limited breeders' exemption in patent law. Accordingly, in such scenarios, difficult evidentiary problems, in particular delicate issues of burden of proof, may arise in case of patent infringement proceedings.

If plant patent claims were explicitly restricted to plants which result from the genome editing technique as disclosed in the patent, it would be the patent holder who had to prove that the plant variety was, or could have been only, generated through the use of the claimed genome-edited plant, e.g. for purposes of crossing.

\footnotetext{
${ }^{4}$ E.g. Godt, "Patentschutz in der (Zier-)Pflanzenzucht", in: Plaschil (ed.), Zweites Symposium Zierpflanzenzüchtung, (2017), p. 28, at 30-31.

5 Which is, according to Rule 26(1)(2) EPC a supplementary means of interpretation of Rules 26 et seqq. EPC and related EPC treaty provisions among them Art. 53(b) EPC.

${ }^{6}$ Commission Notice on certain articles of Directive 98/44/EC of the European Parliament and of the Council on the legal protection of biotechnological inventions (OJ EU C 411, 8.11.2016, 3, at 5 quoting the European Parliament's Rapporteur).
} 
Indeed, one could conclude ${ }^{7}$ from the EBA's decision of 14 May 2020 that patents on genome-edited plants must be explicitly limited to the claimed, or disclosed, process of genome editing, thus excluding plants resulting from essentially biological processes such as crossing and selection. For plants which are "exclusively" obtained by such traditional ("natural") breeding techniques are not patentable and, therefore, should be excluded from the scope of patents on genome-edited plants.

This situation may still not be satisfactory for traditional plant breeders. They typically benefit from the legal regime on plant variety protection. Under the unlimited breeders' exemption in plant variety protection law, plant breeders are free to adopt plant varieties protected by property rights of others for purposes of developing, and marketing, their own new plant variety. For the aforementioned reasons, the plant breeder may fear to become entangled in delicate patent infringement proceedings, though, if the plant variety displays the same trait and mutation as a patented genome-edited plant. From a traditional plant breeder's point of view, it may be preferable to exclude genome-edited plants from patentability all together.

Another point of criticism is that the basic technology, i.e. the CRISPR-Cas technology, as such is patented (albeit the relevant patents have been challenged). Plant breeders who, hitherto, have not been using genetic engineering but are now willing to apply CRISPR-Cas as their preferred new breeding technique may incur difficulties. This is because they might have to acquire licences from the respective patent holders (universities or research institutes in the US) before placing their newly developed plant varieties on the market. Depending on their amount, however, licence fees may exert prohibitive effects on the use of the CRISPR-Cas technology.

In view of all these intricacies and uncertainties, legislators should continuously monitor the factual and legal situation and be prepared for possible amendments to the law. ${ }^{8}$ In the end, the strengths of both patent law and plant variety property rights law should be exploited to incentivize innovation in plant breeding which is urgently needed for the adaptation of agriculture to climate change.

Acknowledgements Open Access funding provided by Projekt DEAL.

Open Access This article is licensed under a Creative Commons Attribution 4.0 International License, which permits use, sharing, adaptation, distribution and reproduction in any medium or format, as long as you give appropriate credit to the original author(s) and the source, provide a link to the Creative Commons licence, and indicate if changes were made. The images or other third party material in this article are included in the article's Creative Commons licence, unless indicated otherwise in a credit line to the material. If material is not included in the article's Creative Commons licence and your intended use is not permitted by statutory regulation or exceeds the permitted use, you will need to obtain permission directly from the copyright holder. To view a copy of this licence, visit http:// creativecommons.org/licenses/by/4.0/.

\footnotetext{
7 Cf. earlier Bayerisches Landesamt für Gesundheit und Lebensmittelsicherheit, Bericht zum Beschluss des Bayerischen Landtags vom 21.06.2017 (Drs. 17/17322) über neue Verfahren in der Gentechnologie, 2017 , p. 22.

${ }^{8}$ Similarly Leopoldina et al., Towards a scientifically justified, differentiated regulation of genome edited plants in the EU, (2019) p. 65.
} 
Publisher's Note Springer Nature remains neutral with regard to jurisdictional claims in published maps and institutional affiliations. 